\title{
Factors associated with the probability of common mental disorders in pregnant women: a cross-sectional study
}

Fatores associados à probabilidade de transtorno mental comum em gestante: estudo transversal Factores asociados a la probabilidad del trastorno mental común en mujeres embarazadas: estudio trasversal

Roselma Lucchese ${ }^{1}$

Naiane Dias Simões ${ }^{1}$

Luiz Henrique Batista Monteiro ${ }^{1}$

Ivânia Vera ${ }^{1}$

Inaina Lara Fernandes ${ }^{1}$

Paulo Alexandre de Castro ${ }^{1}$

Graciele Cristina Silva ${ }^{1}$

Renata Alessandra Evangelista ${ }^{1}$

Alexandre de Assis Bueno ${ }^{1}$

Moisés Fernandes Lemos ${ }^{1}$

1. Universidade Federal de Goiás - Regional Catalão. Catalão, GO, Brazil.
Corresponding Author:

Ivânia Vera

E-mail: ivaniavera@gmail.com

Submitted on $04 / 11 / 2016$.

Accepted on 12/02/2016.

DOI: 10.1590/2177-9465-EAN-2016-0094

\section{Abstract}

Objective: To estimate the prevalence of probability of common mental disorders in pregnant women and associated factors. Methods: A cross-sectional study with a quantitative and descriptive approach was performed with 330 pregnant women enrolled in a Women's Health Service located in Mid-West Brazil. Data were obtained through a questionnaire about socio-demographic characteristics and family or personal history. The Self-Reporting Questionnaire and Poisson regression were applied to screen for common mental disorders, aiming to identify factors associated with it. Results: The prevalence of probability of common mental disorders among pregnant women was $57.1 \%$ and it was associated with marital status, gestational age, unplanned pregnancy and bleeding. Conclusion: The prevalence of pregnant women likely to have common mental disorders and the average Self-Reporting Questionnaire score estimated in this study were higher than those found in other studies with samples from the general population.

Keywords: Pregnant Women; Mental Disorders; Mental Health; Nursing

\section{Resumo}

Objetivo: Estimar a prevalência de probabilidade de transtorno mental comum em gestantes e os fatores associados. Métodos: Estudo transversal, quantitativo e descritivo com 330 gestantes cadastradas em um Serviço de Atenção à Saúde da Mulher Iocalizado no Brasil Central. Os dados foram obtidos por meio de um questionário que abordou características sociodemográficas, antecedentes familiares e pessoais. No rastreamento de transtorno mental comum, aplicaram-se o Self-Reporting Questionnaire e a regressão de Poisson, para verificar os fatores associados a ele. Resultados: A prevalência de probabilidade do desfecho transtorno mental comum em gestantes foi de $57,1 \%$ e esteve associada com as variáveis estado civil, idade gestacional, gravidez planejada e sangramento. Conclusão: A prevalência de gestantes com probabilidade de transtorno mental comum e a média do escore do Self-Reporting Questionnaire estimados nesta pesquisa foram superiores às outras encontradas em estudos com amostras de população geral.

Palavras-chave: Gestantes; Transtornos mentais; Saúde mental; Enfermagem.

\section{Resumen}

Objetivo: Estimar la prevalencia de probabilidad de trastorno mental común en mujeres embarazadas y los factores asociados. Métodos: Estudio trasversal, cuantitativo y descriptivo, realizado con 330 mujeres embarazadas que hacen parte en un Servicio de Atención a la Salud de la Mujer localizado en Brasil Central. Los datos fueron obtenidos por medio de un cuestionario con características sociodemográficas y historias familiares y personales. El Self-Reporting Questionnaire y la regresión de Poisson fueron aplicados en el monitoreo del trastorno mental común para verificar los factores asociados. Resultados: La prevalencia de probabilidad de trastorno mental común en mujeres embarazadas fue del $57,1 \%$, y estuvo asociada con las variables estado civil, edad gestacional, gravidez planeada y sangramiento. Conclusión: La prevalencia de mujeres embarazadas susceptibles de trastornos mentales comunes y el puntaje promedio del Self-Reporting Questionnaire estimado en este estudio fueron superiores a los encontrados en otros estudios de las muestras de población general.

Palabras clave: Mujeres Embarazadas; Trastornos Mentales; Salud Mental; Enfermería. 


\section{INTRODUCTION}

Common mental disorders (CMD) have multi-factorial implications and variations in the biopsychosocial dimensions in which symptoms originating from this nosographic classification raise the functional capacity of individuals. ${ }^{1}$

These changes involve thoughts, feelings, behavior and interpersonal relationships. CMD refer to a group of mental diseases, which include depression, generalized anxiety disorder, panic disorder, phobias, social anxiety disorder, obsessive compulsive disorder, and post-traumatic stress disorder. ${ }^{1}$

The worldwide prevalence of CMD in the general population is $29.2 \%,{ }^{2}$ with a greater prevalence in women, ${ }^{2}$ justified by the change in women's role in society, which implies attributions that overlap, such as domestic and family activities and paid work to support one's family financially. ${ }^{3}$ Associated with these social questions, women are more vulnerable to CMD, as it includes a group of disorders in which epidemiological data point to a higher prevalence of conditions such as anxiety and mood disorders among females. ${ }^{4}$

In the meantime, certain stages of women's life can include factors that can increase their predisposition to CMD, especially during the gestational period, when they experience physical, mental, social and cultural changes. ${ }^{5}$ As an example, hormonal and autonomous changes are observed, which can increase the signs and symptoms of depression and anxiety. Thus, CMD during pregnancy must be recognized and higher chances are associated with low age and level of education, low income and socioeconomic condition, marital status and unemployment. ${ }^{3,6,7}$

The following factors are also associated: living without a partner, planned pregnancy, gestational age and gestational complications. ${ }^{3,5,6,8}$ Thus, the present study is justified when the probability of CMD in this special time women experience and the variables that increase its chances during pregnancy are taken into consideration.

In this perspective, the present study aimed to estimate the prevalence of probability of common mental disorders in pregnant women and associated factors.

\section{METHODS}

A descriptive cross-sectional study with a quantitative approach was performed in a specialized health service for gynecological and obstetric care, situated in Mid-West Brazil in a medium-sized city of regional economic importance. Data were collected between June 2014 and April 2015.

The sample size was estimated from the population of 566 pregnant women registered with the Women's Health Care Center and the expected prevalence of $18.28 \%$ of alcohol and drug abuse during the gestational period ${ }^{9}$; design effect of 1.0; level of significance of $95 \%$; and $99 \%$ confidence interval. A total of $20 \%$ due to sample losses was added to the value obtained, resulting in 361 women interviewed.
The inclusion criteria were pregnant women registered with the abovementioned study, regardless of the gestation period and age (if they were under age, followed by their legal guardian), who were in the health service to have a prenatal consultation. Pregnant women with a diagnosis of Severe and Persistent Mental IIIness (psychotic disorders and bipolar affective disorder) and minors without a legal guardian were excluded.

Participants were invited to participate, instructed about the research project and asked to sign an Informed Consent Form or Term of Agreement (for those aged less than 18 years). Data were obtained from face-to-face interviews with pregnant women in a private location in the health service itself, while they waited for the prenatal consultation, or in the nearest Primary Health Clinic from their home.

A questionnaire about socio-demographic and pregnancy characteristics and the Self-Report Questionnaire 20 (SRQ-20) were applied. The pilot test was performed with six pregnant women to check the adequacy of instruments exclusively and they were not included in the final sample. Field researchers were undergraduate nursing students, qualified through a 12-hour training course and supervised during the entire data collection process by nursing professors and a psychologist.

The SRQ-20 instrument is short and self-administered, which is recommended for Primary Care, whose purpose is to identify the possibility of CMD (non-psychotic) as episodes of mood changes, mood disorders, somatoform disorders and anxiety. Responses refer to the last 30 days, dichotomized into "yes" or "no" and the final score is obtained through the sum of affirmative responses, where each question receives one point. The scores obtained vary from zero (no probability) to 20 (highest probability). Validated in Brazil, the cut-off score for CMD for both sexes is seven or more affirmative responses. ${ }^{10}$

The outcome variable in this study was the probability of CMD, indicated by a score $\geq 7$ through the SRQ-20. The predictor variables were as follows: age, categorized into $>24$ years and $\leq 24$ years; level of education, divided into $\geq 10$ years and $<10$ years; marital status, categorized into "living with a partner" (married or cohabiting) or "living without a partner" (single, widowed, separated or divorced); household income ( $\leq \mathrm{R} \$ 1,581.09$ and $>\mathrm{R} \$ 1,581.09$ or $\leq \mathrm{US} \$ 427.32$ and $>$ US\$ 427.32); number of individuals living in the home (>3 or $\leq 3$ ); report of family history of psychiatric disorders identified by someone that pregnant women consider to be part of the family, even with no kinship ties; whether one has undergone mental health treatment or not (psychiatry); planned pregnancy (information obtained through a direct question); gestational age (<23 weeks or $\geq 23$ weeks based on pregnant women's records); primiparous or not; and episodes of bleeding in the current pregnancy (information obtained through a direct question).

Data were analyzed with Stata Software Package (STATA), version 10.0. The prevalence of probability of CMD was calculated with a $95 \%$ confidence interval $(95 \% \mathrm{Cl})$. A univariate analysis was performed through the measure of effect of Prevalence Ratio (PR), which verifies the difference in prevalences between the 
outcome and predictor variables. Subsequently, variables with a $p<0.10$ were submitted to multivariate analysis with Poisson regression. The chi-square test was applied to verify differences between proportions. Values of $p<0.05$ were considered to be statistically significant.

This research project was approved by the Research Ethics Committee of the Federal University of Goiás, under protocol 523.834/14, in accordance with Resolution number 466/2012, which regulates and foresees the ethical principles for human research in Brazil.

\section{RESULTS}

For the sample calculation, there was a loss of 31 pregnant women (those who spontaneously stopped participating in the study during data collection), totaling 330 participants. Among those interviewed, the mean age was 24.33 years $( \pm 5.9)$, the mean gestational age was 22 weeks $( \pm 11.3)$ and the mean CMD score was $7.74( \pm 4.00)$. Aiming to perform an analysis, 229 individuals were taken into consideration, corresponding to valid responses to the questions asked; of these, 188 (57.1\%; $95 \% \mathrm{Cl} 51.7-62.6$ ) showed a score $\geq 7$ for the SRQ-20 instrument, which represented the prevalence of probability of CMD. Table 1 shows the prevalence of CMD and associated factors estimated in the sample.

In the multiple analysis, the following predictor variables were associated with the outcome variable: marital status $(p=0.01$; $P R=1.09 ; 95 \% \mathrm{Cl} 1.02-1.18)$, planned pregnancy $(p=0.02$; $P R=1.08 ; 95 \% C l$ 1.00-1.16), gestational age $(p=0.01 ; P R=1.08$; $95 \% \mathrm{Cl} 1.01-1.16)$ and bleeding $(p=0.01 ; P R=1.10 ; 95 \% \mathrm{Cl} 1.01-$ 1.19). In Figure 1 we present the prevalence of the "yes" responses to the SRQ-20 questions.

The mean score of responses to the SRQ-20 was 7.74. The "yes" responses to the SRQ-20 questions with the highest prevalence in this study were "feels nervous, tense or worried" (73.9\%), followed by "feels tired easily" $(62.3 \%)$.

\section{DISCUSSION}

The high prevalence of probability of CMD in pregnant women $(57.1 \%)$ was found to be higher than that of the systematic review and meta-analysis of the general population of 63 countries as it revealed a lower percentage (29.2\%) of CMD among the 829,673 individuals analyzed. ${ }^{2}$ At the same time, women have higher prevalences of CMD when compared to men, in terms of mood, depression, anxiety and somatoform disorders. ${ }^{11}$

Consequently, the gestational period is affected by such prevalences, with all the body and lifestyle changes, becoming a stressor for women's experience ${ }^{7}$ This had been confirmed in a previous study with 1,180 pregnant women, as it revealed that symptoms of anxiety (76.7\%) and depression (78.2\%) are more prevalent in young women aged between 17 and 29 years who are married. ${ }^{12}$

In particular, regarding depression symptoms, being single was associated with a higher risk of development of depression during the gestational period, ${ }^{6}$ corroborating the present study in which women living without a partner were more likely to have CMD.

On the other hand, it has been revealed that married women are more susceptible to CMD. In a population-based study performed in Hungary, the Hungarian short version of the Beck Depression Inventory and the Spielberger State-Trait Anxiety Inventory (STAI-T) were applied to 503 pregnant women aged between 15 and 47 years. The majority of pregnant women (60\%) either reported or had a chance of having CMD with depressive symptoms (of which $16.1 \%$ were mild; $2.4 \%$, moderate; and $1.4 \%$, severe) and for anxiety (39.46\%). Women aged less than 20 years had a higher level of depression than older ones (20 to 35 years and higher than 35 years). Moreover, pregnant women who were unemployed and had lower socioeconomic conditions were associated with a high level of depression and anxiety $(p<0.01){ }^{7}$

Low socioeconomic conditions were found in other studies, always indicating the risk of development of CMD. $3,6,7,13$ However, in the present study, there was a negative association between the outcome of CMD and pregnant women with better socioeconomic conditions in the crude PR, although this did not occur in the adjusted PR.

In terms of planned pregnancies, a population-based study conducted in the United States, which applied the Alcohol Use Disorder and Associated Disabilities Interview Schedule IV version (AUDADIS-IV) to pregnant women who planned to have a child and who accepted their pregnancy, showed that they were concerned about the onset of CMD symptoms. According to this study, such result can be explained by the enthusiasm of a mother and interaction with her baby, apart from the increase in social support, which frequently occurs as a result of a new child in the family environment. ${ }^{5}$

The arrival of a new member in the family environment is not always associated with positive feelings. As an example, in Jordan, a prospective study with 353 women aged between 18 and 35 years who were in their last trimester of pregnancy showed a relevant prevalence of depressive symptoms (19\%) during prenatal care, which significantly increased when this pregnancy was not planned (59\%). This occurrence can be partly associated with the cultural norms of this country and the domestic maternal role of women, where being pregnant with a male child is more valued. ${ }^{14}$

In contrast, a cross-sectional study performed in South Korea showed that the pregnancy status of women with a mean age of 30.6 ( \pm 4.0 years) who planned their pregnancy $(83.3 \%)$ did not show an association between pregnancy and depression. ${ }^{15}$

Regarding gestational age, a cohort population-based study performed in Northern Vietnam applied the Edinburgh Postnatal Depression Scale (EPDS-V) to two groups of pregnant women. One group included women with 12 to 20 weeks of pregnancy, whereas the other included those with at least 28 weeks of pregnancy. In terms of CMD, the percentage of reports of symptoms associated with disorders in any gestational period was higher $(39.9 \%)$ in the first group than in the second one $(28.2 \%)$. 
Table 1. Prevalence of probability of common mental disorders (CMD) in pregnant women and associated factors, Mid-West Brazil, 2014-2015.

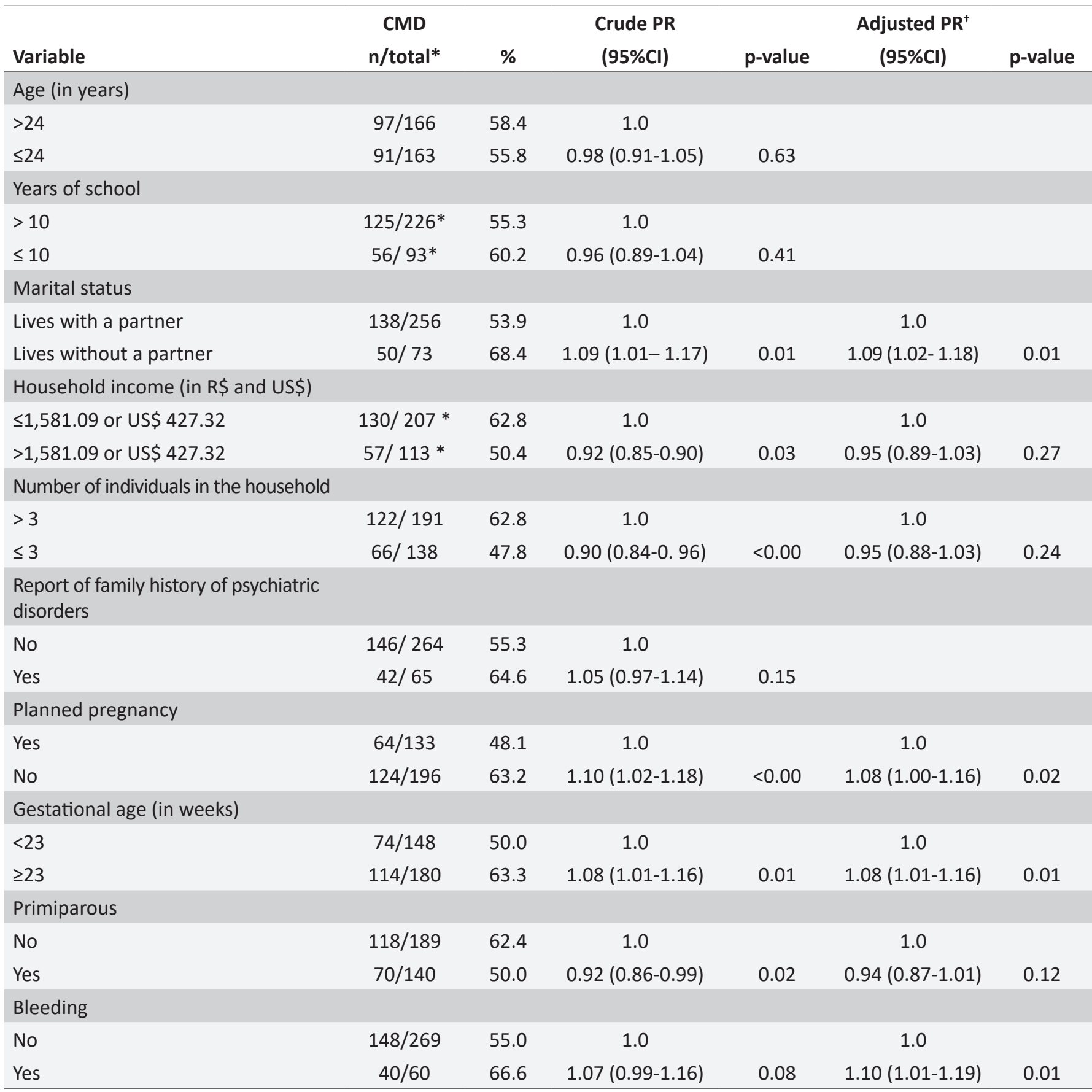

* Denominator represents the number of valid responses; + multivariate: the outcome variable was adjusted to the model: marital status, household income, number of individuals living in the household, planned pregnancy, gestational age, primiparous, bleeding. PR: prevalence ratio; $95 \% \mathrm{Cl}$ : $95 \%$ confidence interval.

The highest prevalence was associated with preference for the sex of a baby, intimate partner violence and financial difficulties. In the second group, symptoms were less prevalent. However, when present, they were associated with economic difficulties and intimate partner violence. ${ }^{3}$

The persistence of CMD symptoms during the pregnancy cycle was associated with aggressive behavior in the family arrangement, partner with a previous and current history of extramarital relationships or alcohol abuse. ${ }^{3}$

In summary, concern about one's health, well-being and/ or the development of one's children, personal history of abortions or stillbirth, child abuse, economic difficulties in life, intimate partner violence and adversities in life are situations that predispose one to CMD during pregnancy. ${ }^{3}$ Although the present 


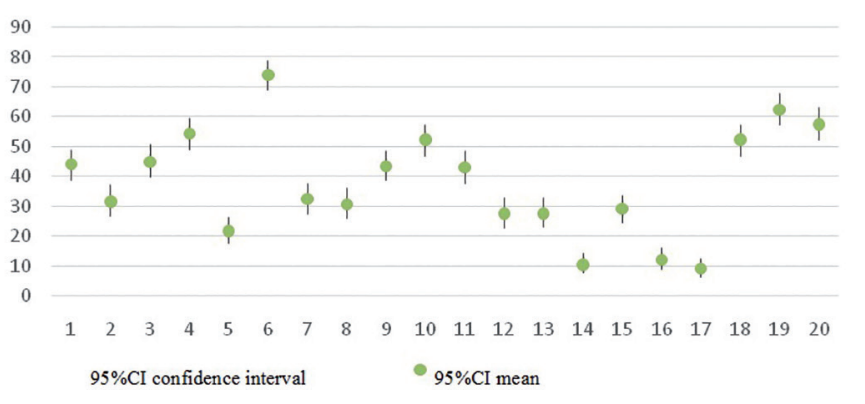

Figure 1. Prevalence and $95 \%$ confidence interval $(95 \% \mathrm{Cl})$ of "yes" responses in the last 30 days to questions from the Self-Reporting Questionnaire 20, Mid-West Brazil, 2014-2015. (1) has frequent headaches (44.1\%); (2) has no appetite (31.6\%); (3) does not sleep well (45.0\%); (4) feels easily frightened (54.4\%); (5) hands shake (21.9\%); (6) feels nervous, tense or worried (73.9 $\%)$; (7) has indigestion (32.5\%); (8) has difficulty to think clearly (30.7\%); (9) has felt sad lately (43.5\%); (10) has cried more than usual (52.3\%); (11) finds it difficult to perform daily activities satisfactorily (43.2\%); (12) finds it difficult to make decisions ( $27.7 \%)$; (13) has difficulties in the service $(27.7 \%)$; $(14)$ is unable to play a useful role in their life (10.6\%); (15) has lost interest in things (29.2\%); (16) feels useless (12.2\%); (17) thinks about committing suicide (9.4\%); (18) feels tired the whole time (52.3\%); (19) feels tired easily (62.3\%); (20) has unpleasant sensations in the stomach (57.4\%). Min: minimum.

study did not investigate violence, it should be emphasized that there is scientific evidence indicating that this phenomenon is associated with CMD, especially intimate partner violence., , $^{36-18}$

A prospective cohort study conducted in Ghana and the Ivory Coast with 1,030 women in their $3^{\text {rd }}$ trimester of pregnancy, in different age groups, revealed high percentages of depression $(28.9 \%)$ and anxiety $(14.2 \%)$. Anxiety was directly associated with age and women aged more than 30 years were the most susceptible ones $(30.6 \pm 5.5)$. The same study revealed that pregnant women described episodes of bleeding during the $1^{\text {st }}$ and $2^{\text {nd }}$ trimesters of pregnancy, which were associated with signs and symptoms that indicated depression and anxiety. ${ }^{8}$

Results from a study performed with pregnant adolescents showed an association between depression and episodes of bleeding. Adolescents who had this complication were 6.7 times more likely to have depression, ${ }^{17}$ evidence that corroborates the results expected for this study.

The present study revealed a score of 7.74 for the SRQ-20 among the pregnant women interviewed. This result is higher than that found in previous studies, which included participants from the community (5.59 and 5.35 points). ${ }^{10,19}$ The highest prevalences of "yes" responses referred to factors that stressed the probability of CMD symptoms, such as those grouped in factor I, which includes symptoms of anxiety, depression and dysphoria, associated with "feels nervous, tense and worried" and "has cried more than usual". In contrast, "feels tired easily" is also associated with depression symptoms. ${ }^{20}$

Regarding factor III for depression and anxiety, responses to "feels easily frightened" are suggested. Factor IV refers to "has unpleasant sensations in the stomach", which implies symptoms of somatic disorders. Moreover, factor VII, related to "feels tired easily" and "feels tired the whole time", indicates different types of neurosis. ${ }^{1,20}$

However, another study that also focused on categorizing SRQ-20 questions with pregnant women showed a higher frequency of "yes" responses for "has frequent headaches", "has felt sad lately" and "has lost interest in things". ${ }^{21}$ In this sense, the most evident factors were the same as those related to depression and anxiety. ${ }^{20}$

\section{CONCLUSION}

The prevalence of pregnant women likely to have common mental disorders and the mean score of the Self-Reporting Questionnaire 20 estimated for the present study were higher than those found in studies with samples from the general population. Furthermore, when compared to estimates of common mental disorders among pregnant women, there was a higher variation in percentage compared to previous studies. However, it should be emphasized that the instruments used were not the same as those from the present study and that the questions from the Self-Reporting Questionnaire 20 refer to symptoms perceived in the last 30 days.

Regarding the variables associated, marital status, planning of pregnancy, gestational age and the occurrence of bleeding should be emphasized as contributions to prenatal care and preparation of professionals who work in the areas of screening, promotion, diagnosis and treatment in health.

These contributions aim to raise awareness of mental health issues during prenatal care to improve nursing reception and consultation. To look at women and identify the factors that increase their chances of having CMD can improve professionals' capacity for nursing diagnosis and, consequently, allow the remaining stages of the process of nursing care to become more effective.

One of the study limitations was the method employed, which does not allow incidences or the cause and effect relationship to be estimated. Another factor is the convenience sample, which represents a certain location, thus limiting generalizations. At the same time, the result of this investigation was similar to those from other studies and it showed that the Self-Reporting Questionnaire 20 instrument, although not confirming the diagnosis of common mental disorder, has the following advantages in the active search for mental health issues among pregnant women: lowcost application, easy management (with the self-administered option) and widely indicated in primary health care.

\section{REFERENCES}

1. National Collaborating Centre for Mental Health (UK). Common Mental Health Disorders: Identification and Pathways to Care [Internet]. Leicester: British Psychological Society; 2011 Jul; [cited 2016 Jan 22] Available from: https://www.ncbi.nIm.nih.gov/books/NBK92254/

2. Steel Z, Marnane C, Iranpour C, Chey T, Jackson JW, Patel V, et al. The global prevalence of common mental disorders: a systematic review and meta-analysis 1980-2013. Int J Epidemiol [Internet]. 2014 Apr 1; [cited 2016 Jan 22]; 43(2):476-93. Available from: http://ije.oxfordjournals.org/ content/43/2/476.long doi: 10.1093/ije/dyu038 
3. Fisher J, Tran T, Duc Tran T, Dwyer T, Nguyen T, Casey GJ, et al. Prevalence and risk factors for symptoms of common mental disorders in early and late pregnancy in Vietnamese women: A prospective population-based study. J Affect Disord [Internet]. 2013 Apr; [cited 2016 Jan 22]; 146(2):213-9. Available from: http://www.jad-journal.com/article/ S0165-0327(12)00635-0/pdf http://dx.doi.org/10.1016/j.jad.2012.09.007

4. American Psychiatric Association (APA). Diagnostic and Statistical Manual of Mental Disorders. 5th ed [Internet]. Washington: American Psychiatric Association; 2013; [cited 2016 Jan 22]. Available from: https://justines2010blog.files.wordpress.com/2011/03/dsm-iv.pdf doi: 10.18848/1833-1882/CGP/v06i06/52093

5. Mota NP, Enns MW, Sareen J. The incidence of mental illness in early motherhood in a population-based survey. J Nerv Ment Dis [Internet]. 2011 Mar;[cited 2016 Jan22]; 199(3):170-5. Available from:https://www.ncbi.nlm. nih.gov/pubmed/21346487 doi: 10.1097/NMD.0b013e31820c73ff

6. Thiengo DL, Fernandes J, Santos DC, Fonseca DL, Abelha L, Lovisi GM. Depressão durante a gestação: um estudo sobre a associação entre fatores de risco e de apoio social entre gestantes. Cad Saúde Colet [Internet].2012; [cited 2016 Jan 22];20(4):416-26. Available from: http://www.scielo.br/scielo. php?script=sci_arttext\&pid=S1414-462X2012000400003\&lng=en http:// dx.doi.org/10.1590/S1414-462X2012000400003

7. Bödecs T, Szilágyi E, Cholnoky P, Sándor J, Gonda X, Rihmer Z, et al. Prevalence and psychosocial background of anxiety and depression emerging during the first trimester of pregnancy: data from a Hungarian population-based sample. Psychiatr Danub [Internet]. 2013 Dec; [cited 2016 Jan 22]; 25(4):352-8. Available from: http://www.hdbp.org/ psychiatria_danubina/pdf/dnb_vol25_no4/dnb_vol25_no4_352.pdf

8. Bindt C, Guo N, Bonle MT, Appiah-Poku J, Hinz R, Barthel D, et al. No association between antenatal common mental disorders in lowobstetric risk women and adverse birth outcomes in their offspring: results from the CDS Study in Ghana and Côte D'Ivoire. PLoS One [Internet]. 2013 Nov 18; [cited 2017 May 8]; 8(11):e80711. Available from: https://www.ncbi.nlm.nih.gov/pmc/articles/PMC3832471/ doi: 10.1371/journal.pone.0080711

9. Kassada DS, Marcon SS, Pagliarini MA, Rossi RM. Prevalence of drug abuse among pregnant women. Acta Paul Enferm [Internet]. 2013; [cited 2016 Jan 22]; 26(5):467-71. Available from: http://www.scielo.br/scielo. php?script=sci_arttext\&pid=S0103-21002013000500010\&Ing=en http://dx.doi.org/10.1590/S0103-21002013000500010

10. Gonçalves DM, Stein AT, Kapczinski F. Avaliação de desempenho do Self-Reporting Questionnaire como instrumento de rastreamento psiquiátrico: um estudo comparativo com o Structured Clinical Interview for DSM-IV-TR. Cad Saúde Pública [Internet]. 2008 Feb; [cited 2016 Jan 22]; 24(2):380-90. Available from: http://www.scielo.br/scielo. php? script=sci_arttext\&pid=S0102-311X2008000200017\&Ing=en http://dx.doi.org/10.1590/S0102-311X2008000200017

11. Skapinakis P, Bellos S, Koupidis S, Grammatikopoulos I, Theodorakis PN, Mavreas V. Prevalence and sociodemographic associations of common mental disorders in a nationally representative sample of the general population of Greece. BMC Psychiatry [Internet]. 2013; [cited 2016 Jan 22]; 13:163. Available from: https://bmcpsychiatry.biomedcentral.com/ articles/10.1186/1471-244X-13-163 doi: 10.1186/1471-244X-13-163

12. Mahenge B, Stöckl H, Likindikoki S, Kaaya S, Mbwambo J. The prevalence of mental health morbidity and its associated factors among women attending a prenatal clinic in Tanzania. Int J Gynecol Obstet [Internet]. 2015 Sep; [cited 2016 Jan 22]; 130(3):261-5. Available from: http://www.ijgo.org/article/S0020-7292(15)00322-7/abstract http:// dxdoi.org/10.1016/j.ijgo.2015.04.032
13. Fortner RT, Pekow P, Dole N, Markenson G, Chasan-Taber L. Risk factors for prenatal depressive symptoms among hispanic women. Matern Child Health J. [Internet]. 2011; [cited 2016 Jan 22]; 15(8):128795. Available from: https://www.ncbi.nlm.nih.gov/pmc/articles/ PMC3737772/ doi: 10.1007/s10995-010-0673-9

14. Mohammad KI, Gamble J, Creedy DK. Prevalence and factors associated with the development of antenatal and postnatal depression among Jordanian women. Midwifery [Internet]. 2011 Dec; [cited 2016 Jan 22]; 27(6):e238-45. Available from: https://www.ncbi.nlm.nih.gov/ pubmed/21130548 doi: 10.1016/j.midw.2010.10.008

15. Jung Y, Park CM, Seo H, Kim MD, Hong SC, Bahk WM, et al. Factors associated with antenatal depression in pregnant Korean females: the effect of bipolarity on depressive symptoms. Neuropsychiatr Dis Treat [Internet]. 2014 Jun; [cited 2016 Jan 22]; 10:1017-23. Available from: https://www.dovepress.com/factors-associated-with-antenataldepression-in-pregnant-korean-female-peer-reviewed-article-NDT https://doi.org/10.2147/NDT.S63855

16. Ribeiro WS, Andreoli SB, Ferri CP, Prince M, Mari JJ. Exposição à violência e problemas de saúde mental em países em desenvolvimento: uma revisão da literatura. Rev Bras Psiquiatr [Internet]. 2009 Oct; [cited 2016 Jan 22]; 31(Supl.2):S49-57. Available from http://www.scielo.br/scielo.php?script=sci_arttext\&pid=S1516$44462009000600003 \&$ Ing $=$ en http://dx.doi.org/10.1590/S151644462009000600003

17. Pereira PK, Lovisi GM, Lima LA, Legay LF. Complicações obstétricas, eventos estressantes, violência e depressão durante a gravidez em adolescentes atendidas em unidade básica de saúde. Rev Psiquiatr Clín [Internet]. 2010; [cited 2016 Jan 22]; 37(5):216-22. Available from: http://www.scielo.br/scielo.php?script=sci_arttext\&pid=S0101$60832010000500006 \&$ Ing =en http://dx.doi.org/10.1590/S0101 60832010000500006

18. Ola B, Crabb J, Tayo A, Gleadow Ware SH, Dhar A, Krishnadas R. Factors associated with antenatal mental disorder in West Africa: A cross-sectional survey. BMC Pregnancy Childbirth [Internet]. 2011; [cited 2017 May 8]; 11:90. Available from: http://bmcpregnancychildbirth. biomedcentral.com/articles/10.1186/1471-2393-11-90 doi: 10.1186/1471-2393-11-90

19. Lucchese R, Sousa K, Bonfin SP, Vera I, Santana FR. Prevalence of common mental disorders in primary health care. Acta Paul Enferm [Internet]. 2014 Jun; [cited 2016 Jan 22]; 27(3):200-7. Available from: http://www.scielo.br/scielo.php?script=sci_arttext\&pid=S0103$21002014000300200 \&$ Ing $=$ en http://dx.doi.org/10.1590/19820194201400035

20. World Health Organization (WHO). A User's Guide to the Self Reporting Questionnaire (SRQ) [Internet]. Geneva: WHO; 1994 [cited 2016 Jan 22]; p.1-84. Available from: http://apps.who.int/iris/ bitstream/10665/61113/1/WHO_MNH_PSF_94.8.pdf

21. Hanlon C, Medhin G, Alem A, Araya M, Abdulahi A, Hughes M et al. Detecting perinatal common mental disorders in Ethiopia Validation of the self-reporting questionnaire and Edinburgh Postnatal Depression Scale. J Affect Disord. [Internet]. 2008 Jun; [cited 2016 Jan 22]; 108(3):251-62. Available from: http://www.jad-journal.com/ article/S0165-0327(07)00384-9/abstract http://dx.doi.org/10.1016/j. jad.2007.10.023 